\title{
Kedudukan Manusia
}

\author{
Inwanatun Nuriyah \\ UIN Alauddin Makassar \\ Email: nuriyahinwanatun@gmail.com
}

\begin{abstract}
ABSTRAK
Tulisan ini bermaksud mengulas kedudukan sebagai makhluk individu dan makhluk sosial. Hal ini dengan tujuan memberi wawasan kepada warga bangsa dalam hal: memahami hakikat manusia yang menjadi makhluk individu; dan memahami hakikat manusia yang menjadi makhluk sosial.
\end{abstract}

Kata Kunci : Kedudukan, Manusia, Individu, Sosial

\section{Pendahuluan}

Manusia atau orang dapat diartikan berbeda dalam hal istilah biologi, spiritual, dan budaya, atau campuran. Secara biologis, manusia diklasifikasikan sebagai Homo sapiens, sebuah spesies primata dari mamalia yang mencakup otak sangat mampu. Dalam hal kerohanian, mereka dijelaskan menggunakan konsep jiwa yang bervariasi di mana, dalam agama, dimengerti dalam hubungannya dengan kekuatan Tuhan atau makhluk hidup; dalam mitos, mereka juga seringkali dibandingkan dengan ras lain.

\section{Pembahasan}

\section{Kedudukan Manusia Sebagai Makhluk Individu}

Manusia itu disebut individu bila pola tingkah lakunya bersifat spesifik dirinya dan bukan lagi mengikuti pola tingkah laku umum. Ini berarti bahwa individu adalah seorang manusia yang tidak hanya memiliki peranan-peranan yang khas didalam lingkungan sosialnya, melainkan juga mempunyai kepribadian serta pola tingkah laku spesifik dirinya. Didalam suatu kerumunan massa manusia cenderung menyingkirkan individualitasnya, karena tingkah laku yang ditampilkannya hampir identik dengan tingkah laku masa

Adapun kedudukan manusia sebagai makhluk makhlik individu adalah manusia sebagai makhluk Tuhan Yang Maha Esa. 
Manusia sebagai makhluk individu diartikan sebagai person atau perseorangan atau sebagai diri pribadi. Manusia sebagai diri pribadi merupakan makhluk yang diciptakan secara sempurna oleh Tuhan Yang Maha Esa. Disebutkan dalam Kitab Suci Al Quran bahwa Sesungguhnya Kami telah menciptakan manusia dalam bentuk yang sebaik-baiknya.

\section{Pengembangan Manusia Sebagai Makhluk Individu}

Sebagai makhluk individu yang menjadi satuan terkecil dalam suatu organisasi atau kelompok, manusia harus memiliki kesadaran diri yang dimulai dari kesadaran pribadi di antara segala kesadaran terhadap segala sesuatu. Kesadaran diri tersebut meliputi kesadaran diri di antara realita, self-respect, self-narcisme, egoisme, martabat kepribadian, perbedaan dan persamaan dengan pribadi lain, khususnya kesadaran akan potensi-potensi pribadi yang menjadi dasar bagi self-realisation.

Sebagai makhluk individu manusia mempunyai suatu potensi yang akan berkembang jika disertai dengan pendidikan. Pada dasarnya, pendidikan mem- punyai arti penting bagi kehidupan ma- nusia, yaitu pendidikan diakui sebagai kekuatan yang dapat mendorong manusia mencapai kemajuan peradaban. Selain itu, pendidikan memberikan bekal kepada manusia untuk menyongsong hari esok yang lebih cerah dan manu- siawi. Persoalan pendidikan memang masalah yang sangat penting dan aktual sepanjang masa, karena hanya dengan pendidikanlah manusia akan memperoleh pengetahuan dan keterampilan dalam kapabilitas mengelola alam yang dikaruniakan Tuhan kepada makhluk- Nya. Melalui pendidikan, manusia dapat menggali dan mengoptimalkan segala potensi yang ada pada dirinya. Melalui pendidikan pula manusia dapat mengembangkan ide-ide yang ada dalam pikirannya dan menerapkannya dalam kehidupannya sehari-hari yang dapat meningkatkan kualitas hidup manusia itu sendiri.

\section{Kedudukan Manusia Sebagai Makhluk Sosial}

Manusia adalah makhluk yang selalu berinteraksi dengan sesamanya. Manusia tidak dapat mencapai apa yang diinginkan dengan dirinya sendiri. Sebagai makhluk sosial karena manusia menjalankan peranannya dengan menggunakan simbol untuk mengkomunikasikan pemikiran dan perasaanya. Manusia tidak dapat menyadari individualitas, kecuali melalui medium kehidupan sosial.

Esensi manusia sebagai makhluk sosial pada dasarnya adalah kesadaran manusia tentang status dan posisi dirinya adalah kehidupan bersama, serta bagaimana tanggungjawab dan kewajibannya di dalam kebersamaan. 
Manusia sebagai makhluk sosial artinya manusia sebagai warga masyarakat. Dalam kehidupan sehari-hari manusia tidak dapat hidup sendiri atau mencukupi kebutuhan sendiri. Meskipun dia mempunyai kedudukan dan kekayaan, dia selalu membutuhkan manusia lain. Setiap manusia cenderung untuk berkomunikasi, berinteraksi, dan bersosialisasi dengan manusia lainnya. Dapat dikatakan bahwa sejak lahir, dia sudah disebut sebagai makhluk sosial.

Hakekat manusia sebagai makhluk sosial dan politik akan membentuk hukum, mendirikan kaidah perilaku, serta bekerjasama dalam kelompok yang lebih besar. Dalam perkembangan ini, spesialisasi dan integrasi atau organissai harus saling membantu. Sebab kemajuan manusia nampaknya akan bersandar kepada kemampuan manusia untuk kerjasama dalam kelompok yang lebih besar. Kerjasama sosial merupakan syarat untuk kehidupan yang baik dalam masyarakat yang saling membutuhkan.

Kesadaran manusia sebagai makhluk sosial, justru memberikan rasa tanggungjawab untuk mengayomi individu yang jauh lebih "lemah" dari pada wujud sosial yang "besar" dan "kuat". Kehidupan sosial, kebersamaan, baik itu non formal (masyarakat) maupun dalam bentuk-bentuk formal (institusi, negara) dengan wibawanya wajib mengayomi individu.

\section{Pengembangan Manusia Sebagai Makhluk Sosial}

Di dalam kehidupannya, manusia tidak hidup dalam kesendirian. Manusia memiliki keinginan untuk bersosialisasi dengan sesamanya. Ini merupakan salah satu kodrat manusia adalah selalu ingin berhubungan dengan manusia lain. Hal ini menunjukkan kondisi yang interdependensi. Di dalam kehidupan manusia selanjutnya, ia selalu hidup sebagai warga suatu kesatuan hidup, warga masyarakat, dan warga negara.

Dalam berhubungan dan berinteraksi, manusia memiliki sifat yang khas yang dapat menjadikannya lebih baik. Kegiatan mendidik merupakan salah satu sifat yang khas yang dimiliki oleh manusia. Imanuel Kant mengatakan, "manusia hanya dapat menjadi manusia karena pendidikan". Jadi jika manusia tidak dididik maka ia tidak akan menjadi manusia dalam arti yang sebenarnya. Hal ini telah terkenal luas dan dibenarkan oleh hasil penelitian terhadap anak terlantar. Hal tersebut memberi penekanan bahwa pendidikan memberikan kontribusi bagi pembentukan pribadi seseorang.

Dengan demikian manusia sebagai makhluk sosial berarti bahwa disamping manusia hidup bersama demi memenuhi kebutuhan jasmaniah, manusia juga hidup bersama dalam memenuhi kebutuhan rohani. 


\section{Penutup}

\section{Kesimpulan}

Secara biologis, manusia diklasifikasikan sebagai Homo sapiens, sebuah spesies primata dari mamalia yang mencakup otak sangat mampu. Manusia sebagai makhluk individu diartikan sebagai person atau perseorangan atau sebagai diri pribadi. Manusia sebagai diri pribadi merupakan makhluk yang diciptakan secara sempurna oleh Tuhan Yang Maha Esa. Disebutkan dalam Kitab Suci Al Quran bahwa Sesungguhnya Kami telah menciptakan manusia dalam bentuk yang sebaik-baiknya.

Esensi manusia sebagai makhluk sosial pada dasarnya adalah kesadaran manusia tentang status dan posisi dirinya adalah kehidupan bersama, serta bagaimana tanggungjawab dan kewajibannya di dalam kebersamaan, manusia sebagai makhluk sosial berarti bahwa disamping manusia hidup bersama demi memenuhi kebutuhan jasmaniah, manusia juga hidup bersama dalam memenuhi kebutuhan rohani.

\section{Daftar Pustaka}

Anggraeni, A. (2020). Menegaskan Manusia sebagai Objek dan Subjek Ilmu Pendidikan. Pelita Bangsa Pelestari Pancasila, 15(1), 60-74.

https://www.dosenpendidikan.co.id/manusia-sebagai-makhluk-sosial/ 